\title{
Reflexión teológico-espiritual del diálogo: Dios-ser humano, ser humano-ser humano"
}

\author{
Amparo Alvarado Palacios ${ }^{* *}$ \\ Recepción: 14 de diciembre de 2017 • Aprobación: 22 de enero de 2018
}

\section{Resumen}

Se pretende buscar, en la dinámica de la comunicación divina, la plataforma teológica del diálogo. La antropología teológica del misterio de la Revelación y su espiritualidad explican la certeza de un evento espiritual: el diálogo. La espiritualidad de la Revelación es la fuente que explica el nacimiento, el progreso y el desarrollo de la vida espiritual, puesto que, si Dios se revela, es para asociar al ser humano a su vida íntima y este, por la fe, se abre a Dios: un diálogo que lleva a la comunión de vida en el Espíritu. Es un encuentro interpersonal que compromete al ser humano con Dios, con los otros y con el cosmos, que produce un cambio de vida existencial y, por tanto, permanente.

Palabras clave: diálogo, escucha-respuesta, encuentro, espiritualidad.

* El artículo es resultado de la investigación doctoral realizada por la autora, la cual llevó por título La mística del diálogo como camino espiritual para una santidad en y para el mundo: hacia una espiritualidad laical para América Latina. Citar como: Alvarado Palacios, A. (2018). Reflexión teológico-espiritual del diálogo: Dios-ser humano, ser humano-ser humano. Revista Albertus Magnus, IX(1), 11-42. Doi: https://doi.org/10.15332/s2011-9771.2018.0001.01

* Instituto Sur Andino de Investigación y Acción Solidaria, Perú. Correo electrónico: florderetama77@gmail.com 


\title{
Theological-spiritual reflection of the dialogue: God-human being, human being-human being
}

\begin{abstract}
The aim is to search in the dynamics of divine communication, the theological platform of dialogue. The theological anthropology of the mystery of revelation and its spirituality explain the certainty of a spiritual event: dialogue. The spirituality of revelation is the source that explains the birth, progress and development of the spiritual life, since if God reveals himself, it is to associate the human being with his intimate life and this, by faith, is opened to God. A dialogue that leads to the communion of life in the Spirit. Interpersonal encounter that engages the human being with God, with others and with the cosmos and that produces a change of existential life and therefore permanent.
\end{abstract}

Keywords: dialogue, listening-response, encounter, spirituality.

\section{Reflexão teológico-espiritual do diálogo: Deus-ser humano, ser humano-ser humano}

\section{Resumo}

Neste escrito se quer mostrar na dinâmica da comunicação divina, a proposta teológica do diálogo. A antropologia teológica do mistério da revelação e sua espiritualidade, ilustram com certeza como evento espiritual: o diálogo. A espiritualidade de revelação é a fonte que explica o nascimento, o progresso e o desenvolvimento da vida espiritual, pois se Deus revela-se é para associar ao ser humano a sua vida íntima e ele, pela fé, se abre a Deus. Um diálogo que leva a uma comunhão de vida no Espírito. Encontro interpessoal que compromete ao ser humano com Deus, com os outros/as e com o cosmos e que produz uma mudança de vida existencial e por tanto é permanente.

Palavras-chave: diálogo, escuta-resposta, encontro, espiritualidade.

\section{Introducción}

Este artículo se corresponde con una parte del segundo capítulo de la tesis doctoral de la autora, titulada La mística del diálogo como camino espiritual para una santidad en y para el mundo: hacia una espiritualidad laical para América 
Latina. El primer capítulo contiene básicamente la situación de la espiritualidad laical en América Latina a partir de los documentos de las Conferencias Generales del Episcopado desde Medellín hasta Aparecida. El segundo capítulo abarca tres temas de fondo: a) la antropología teológica del diálogo Dios-ser humano, ser humano-ser humano y ser humano-cosmos; b) la eclesiología conciliar y posconciliar; y c) la de definición de la autora en torno a la espiritualidad laical. Sobre esta base se construye el tercer capítulo como una propuesta de un camino de espiritualidad laical: la mística del diálogo.

Este artículo pretende ofrecer un estudio teológico del diálogo como evento espiritual. Si bien las reflexiones teológicas que se leerán no son novedosas, lo son vistas como fundamento de tal evento espiritual, ya que es de la riqueza de la vida espiritual que nace y se desarrolla la teología. Desde una experiencia de Dios, se explicita la reflexión sobre Él, ya que la fe es fundamentalmente una experiencia de relación con Dios. Se pueden leer en la Biblia innumerables testimonios de ello, corroborado por los santos y todos los que confiesan al Dios vivo de Jesucristo. Esta experiencia de diálogo, tan humana como divina, se da en la historia particular y colectiva de los creyentes a lo largo de los siglos y encuentra en Cristo su plenitud. Se describe a continuación una reflexión teológica espiritual del diálogo: Dios-ser humano, ser humano-ser humano.

\section{Dios inicia el diálogo de amistad con el ser humano}

\subsection{Dios se da a conocer hablando: la Revelación}

A la base de la fe, de la teología y, por ende, de la espiritualidad, está la verdad fundamental: Dios es el primero no solo como convicción sino como experiencia, así como el reconocer que esta experiencia y conocimiento es un acto provocado por Dios en su voluntad salvífica. Por tanto, conocer y experimentar pasa a ser una sola realidad de gracia, más de las veces posteriormente explicitada en lenguaje teológico, ya que "el diálogo de la salvación fue abierto espontáneamente por iniciativa divina: Él nos amó el primero" (Ecclesiam suam, n. 39). Como bien lo recuerda Rahner (1967):

La teología en su esencia primigenia no es, ni mucho menos, una ciencia cuya constitución sea llevada a cabo por el hombre mismo. Originariamente es la teología de la audición - aunque iluminada - de la Revelación que Dios hace de sí mismo, conforme a su libre designio, por medio de su palabra. La teología [...] no es un sistema de proposiciones 
valederas constituidas por un pensar humano, sino la totalidad del hablar divino. (p. 21)

Este proyecto de salvación es ante todo un deseo de comunión de parte de Dios para con su pueblo; es un acto de amor iniciado por Dios Padre y realizado plenamente en Cristo: "Dios, desde tiempos antiguos ha hablado de muchas maneras al hombre por medio de profetas $\mathrm{y}$, últimamente, ha hablado por medio de su Hijo" (Hb 1, 1-2). Su ser divino es expresado en su relación amorosa con los seres humanos. El Dios hablante es el que deviene accesible para el lenguaje humano, es decir, se hace palabra, no como logos ratio, sino como logos verbum, precisamente para encontrar en el ser humano su privilegiado interlocutor. Así lo corrobora Dartigues (1993):

El misterio no se revela solo como idea en el espacio monológico de la razón, sino más bien como Palabra en el espacio dialógico de interlocución. La reserva del secreto del Misterio divino corresponde menos a una voluntad de esconderse que a una voluntad de comunicarse en su misma esencia, por tanto, en su alteridad o su diferencia con el hombre. (p. 253)

En este espacio de interlocución, hay que distinguir la naturaleza de cada interlocutor. "Dios habla para poner el pensamiento del hombre en comunicación con su propio pensamiento" (León-Dufour, 1972). Es propio de Dios la iniciación del diálogo, pronunciando su palabra, interpelando al escuchante: “Escucha, Israel: Yahveh, nuestro Dios, es Yahveh único" (Dt 6, 4), y del ser humano es propio el escuchar y responder a esa Palabra según el pensamiento de Dios. Con esto no se quiere decir que Dios no escuche ni que el ser humano no hable. Solo se quiere destacar que en el encuentro entre Dios y el ser humano Aquel es preeminente y este, desde abajo, lo escucha y lo acoge. El ser humano sigue siendo tal también cuando es Dios quien le habla. La capacitas humana en orden a la gracia y a la Palabra de Dios es siempre una capacitas finita. De este hablar de Dios que marca la diferencia habla abundantemente el Antiguo y Nuevo Testamento, desde el dabàr ${ }^{1}$ de Yahveh hasta el Logos sarx.

La Palabra de Dios, el dabàr Yahveh, está llena de fuerza y poder (Gn 1; Is 40,$8 ; 55,10 ;$ Jr 23, 29; Sal 33, 4, 9; Jr 5, 14; Is 9, 7). Fuerza y poder porque en la

1 Dábár deriva de dbr que significa hablar. En el Antiguo Testamento, se usa para designar la comunicación de Dios con los hombres, su autorrevelación. La totalidad de esa Revelación se denomina Torá. 
concepción del dabàr veterotestamentario está íntimamente unida a la acción, al acontecimiento. Dios habla y actúa. Es manifestación de su "sabiduría", presente ya cuando estructura el universo inteligentemente: “Y dijo Dios: 'sea el mundo' y el mundo fue" (Gn 1, 3). El decir de Dios se va haciendo cada vez más personal a partir de su presentación al pueblo de Israel: "Yo soy el que soy" (Ex 3, 14). Dios habla por medio de la Ley, de la Torah. Dios habla por medio de los profetas, les dice: "serás como mi boca" (Jr 15, 19).

El hablar de Yahveh está, por eso, siempre revestido de experiencias concretas y de incidencia histórica. Son palabras para cada momento. Esta característica del hablar divino se manifiesta de muchas maneras: como promesa (Gn 12, 1-3, 7; Ex 34, 10; 2S 7, 10, 24) y amenaza (2 R 17, 13), como exigencia y mandato (Dt 4, 12, 10, 4, 15, 28, 14; Jos 1, 8, entre otros) y como fuerza creadora (Gn 1 y 2; Sb 9, 1 y ss; Si 39, 23; 42, 15 y ss.). En los profetas, “900 veces se subraya que la palabra transmitida no es ocurrencia personal, sino como Palabra de Dios" (Sicre, 1992, p. 110). La Palabra de Yahveh refiere a su coherencia divina. Así, su exigencia manifiesta su voluntad ética y sus normas su voluntad de comunión con su pueblo. Por eso, en la comunicación Yahveh-pueblo, se da a la vez mandato y diálogo; ambos aspectos son parte de una verdadera comunión.

\subsection{Dios se dice plenamente en Cristo}

No obstante, el hablar de Dios — cada vez más profundo a medida que progresa la Revelación - se hace pleno cuando, más allá de los decires y palabras del universo y del Antiguo Testamento, finalmente se dice a sí mismo, se presenta definitivamente, abre las puertas de lo que es en su santidad y trascendencia en Jesús de Nazaret. Jesús no solo transmite palabras de Dios. Jesús es la Palabra de Dios, la Revelación suprema, la Sabiduría, ${ }^{2}$ el Verbo. En Cristo, se hace el decir definitivo de Dios a la humanidad tanto en su vivir y morir como en su resucitar. Por eso,

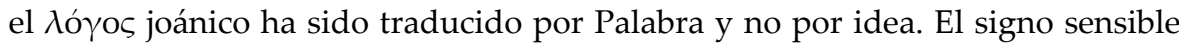
de la plena locución de Dios es la humanidad del Verbo (Jn 1, 14, 18). Dios habla en su Verbo una sola vez y totalmente $(\mathrm{Hb} 1,1)$. Como se dice en la DeiVerbum:

2 Hay que entender el Logos de Juan dentro de la literatura sapiencial sobre la Sabiduría personificada que explica la razón de ser de su prólogo frente a relaciones gnósticas. El contenido del prólogo guarda gran afinidad con Si 24, Pr 8, Bar 3, 9-4 y Sb 6-9. Esta tradición profética y sapiencial de la Palabra es divina, reveladora, creadora, salvadora y reveladora de los designios de Dios (Gn 1; Sal 33, 6; 148, 5; Is 55, 10-11; Sal 50, 2; Is 42, 14; Sb 9, 1-2). 
Jesucristo, pues, el Verbo hecho carne, "hombre enviado, a los hombres", "habla palabras de Dios" y lleva a cabo la obra de la salvación que el Padre le confió. Por tanto, Jesucristo - ver al cual es ver al Padre-, con su total presencia y manifestación personal, con palabras y obras, señales y milagros, $\mathrm{y}$, sobre todo, con su muerte y resurrección gloriosa de entre los muertos; finalmente, con el envío del Espíritu de verdad, completa la revelación y confirma con el testimonio divino que vive en Dios con nosotros para librarnos de las tinieblas del pecado y de la muerte y resucitarnos a la vida eterna. (n. 4)

“En la persona de Cristo [...] el que habla y la Palabra están uno en el otro, la Palabra es el Que habla y el Que habla es la Palabra" (Dartigues, 1993, p. 248). A lo largo de los Evangelios se ve que Jesús se pone a sí mismo en oposición a la Torá, se coloca como Palabra de Dios: "antes se os dijo [...] ahora Yo os digo". Jesús declara de "todo el que oiga estas palabras mías" (Mt 7, 24-27), y así muestra la fuerza de su hablar. Del mismo modo, el $\varepsilon \gamma \omega \dot{\varepsilon}\{\dot{\mu} \alpha \iota$ de Jesús reivindica una autoridad divina. Jesús hace depender la decisión del escuchar y cumplir sus propias palabras, distinguiendo su palabra aun de las máximas pretensiones de los profetas: sus palabras no pasan (Mc 8,$38 ; 13,31)$. La autoridad de las palabras de Jesús se muestra también en su llamada a que le sigan: "ven y sígueme" (Mt 9, 9; 19, 21; Mc 1, 16 y ss.; 2, 14; 10, 21; Lc 18, 22; Jn 21, 22). También se muestra en la reacción de los oyentes, quienes, o bien se escandalizan, o bien se admiran porque les enseña con autoridad, no como sus letrados. En sus palabras, se transparenta el núcleo de la pretensión de su misión. Se advierte en Jesús la continuidad con el Antiguo Testamento, en la unidad de palabra y acción de Yahveh.

Todo lo que Dios quería comunicar y dar al mundo encuentra lugar en Jesucristo. "El Hijo es el narrador del Padre" (Vergauwen, 1993, p. 593). "El sustantivo bíblico pleroma intensifica su carácter fecundo, pues en dicho concepto se funden tres significados: lo que es llenado, lo que llena y la plenitud en sentido de sobreabundancia. Tal riqueza solo se puede aplicar a Cristo" (p. 344). La constitución Dei verbum habla de la vida que se manifiesta en la persona de Cristo, que no solo es escuchado, sino visto y tocado (1 Jn 1, 1-2), que revela comunicando vida. La comunión que Dios quiere con su Pueblo tiene por condición para este la escucha y respuesta libre. Escuchar es condición de que la Palabra de Yahveh se haga vida en el ser humano y en el pueblo; así se realiza la Alianza. ${ }^{3}$

3 "Ahora, pues, si de veras obedecéis y guardáis mi alianza" (Ex 19, 5). "Entonces me dijo: 'Profetiza sobre estos huesos. Les dirás: ¡Huesos secos, escuchad la palabra de Yahvé!'” (Ez 


\section{El ser humano es quien escucha y responde a Dios}

El hombre es el ser creado como oyente de la Palabra, como quien en la respuesta a la palabra se iza a su propia dignidad. En su más íntima entraña, está dialógicamente diseñado. Su inteligencia está dotada con una luz propia exactamente adecuada para lo que necesita, para escuchar al Dios que le habla (Von Balthasar, 1985).

Si el Dios bíblico es comunicación originaria, este por gracia es receptividad histórica (Pikaza, 2006). "La persona humana es siempre y desde el principio relación total a Dios" (Andrade, 1999, p. 103). Es una relación ascendente por esencia: el ser humano busca a Dios como al que es siempre antes y más que él; ante quien le queda escuchar, acoger y responder en obediencia. Cuando Yahveh habla, hay que escuchar y obedecer (Am 3, 8, 13; 4, 1; Is 8, 5; 1, 10, 20; Os 1, 2; Za 1, 9; 16, 13; Jr 1, 7; 20, 8 y ss.; 27, 13). En la dinámica del darse de Dios y del acogerresponder humano, se tejerá la historia salvífica. "Tanto en el Antiguo como en el Nuevo Testamento, Dios habla para ser escuchado $(\mathrm{Hb} 12,25)$ y creído $(\mathrm{Hb} 4$, 2). Para suscitar la única respuesta del hombre: la fe" (Latourelle, Fisichella y PiéNinot, 1992, p. 1235). Como dice Pablo: "la fe viene de la audición" (Rm 10, 17). El pueblo de Israel construyó su historia según esa receptividad creyente ante las palabras-acciones de Dios.

\subsection{Ante el hablar de Dios es imperativo el escuchar del ser humano}

El ser humano bíblico descubrió que estar vivo era lo mismo que haber escuchado a Dios: "Hemos visto en este día que puede Dios hablar al hombre y seguir este con vida" (Dt 5, 24); “Te humilló, te hizo pasar hambre, te dio a comer el maná que ni tú ni tus padres habíais conocido, para mostrarte que no solo de pan vive el hombre, sino que el hombre vive de todo lo que sale de la boca de Yahveh" (Dt $8,3)$. Lo que sale de la boca de Dios es su Palabra, su llamado, su invitación, su mandato y su promesa. Alimentarse de esa Palabra es escucharla. Unida al hablar de Dios está la invitación imperativa a escuchar. Palabra repetida en la Biblia: la dice el profeta (Am 3, 1; Jr 7, 2); la dicen los sabios (Pr 1, 8); la invocan al acogerse

37, 4). "Para hacerte saber que no sólo de pan vive el hombre, sino que el hombre vive de todo lo que sale de la boca de Yahveh" (Dt 8, 3b). "Aplicad el oído y acudid a mí, oíd y vivirá vuestra alma. Pues voy a firmar con vosotros una alianza eterna" (Is 55, 3). 
a la voluntad de Dios (Dt 6, 4; 20, 3; Mc 12, 29) y el mismo Jesús la repite (Mc 4, 3, 9) (León-Dufour, 1972).

¿Por qué el escuchar tipifica al israelita? Wolf (1997) ilustra al respecto. Explica que el oír o estar sordo identifica la vida humana, o como persona en sí, o en relación con los demás seres humanos, o en relación con su Dios. El oír en la cultura hebrea hace de la comunicación algo típicamente humano. El que está en peligro de quedarse sordo tiene que temer por su propia existencia. Oír es lo que lo constituye al hombre y, consecuentemente, abrir la boca y contestar desde lo escuchado: "Pero yo, me hago el sordo y nada oigo, como un mudo que no abre la boca; soy como un hombre, ni tiene réplica en sus labios" (Sal 38, 14ª , 15); "Quien rechaza la educación se desprecia a sí mismo; quien escucha la reprensión adquiere cordura" (Pr 15, 32).

No es raro mencionar juntos el ojo y el oído: “Oído que escucha y ojo que ve: ambas cosas las hizo Yahveh" (Pr 20, 12); "Haced salir al pueblo ciego, aunque tienen ojos y aunque tienen orejas" (Is 43, 8); para decir que el abrir los ojos se debe a la palabra escuchada. También gracias al oír humano es posible sentirse ubicado, perteneciente a un lugar y por ende a una raza: "He tenido una revelación furtiva, mis oídos han captado su susurro" (Jb 4,12). "Estas son las leyes que les expondrás" (Ex 21, 1). Se ve cómo el hombre se moviliza completamente por el oído. La audición del sabio cambia la situación total de su cuerpo y, así, el oír determina la conducta y el destino del ser humano en sí (Gn 3, 8-10). Por eso para Salomón es más importante un corazón presto a la escucha que una vida larga (Pr 18, 13) (Wolff, 1997).

El escuchar al Dios que habla, en la antropología bíblica, supone el hecho en sí de la audición, pero incluye el guardar lo oído. Esta finalidad está relacionada en la Biblia con el ejercicio de la función de la memoria para recordar y con la función del corazón para acoger, discernir y adherirse a lo oído: “¡Ojalá escuchéis hoy su voz!" (Sal 95, 8). La finalidad de recuerdo de la Palabra escuchada se cumple cuando el pueblo se siente invitado a adherirse con el corazón a dicha palabra: "Y ahora, Israel, escucha los preceptos y las normas que yo os enseño, para que las pongáis en práctica" (Dt 4,1). De este modo al escuchar interviene el oído y el corazón (Pasquetto, 1997).

En la acogida del corazón, será finalmente donde se dará la aceptación y obediencia a la palabra escuchada: "Una de ellas, llamada Lidia [...] nos escuchaba. El Señor le abrió el corazón para que se adhiriese a las palabras de Pablo" (Hch 16, 14). La Palabra de Dios también tiene la finalidad de observancia y la cumple provocando en el pueblo obediencia tanto desde el corazón como en la práctica: “Guarda los preceptos y los mandamientos que yo te prescribo hoy, para que 
seas feliz, tú y tus hijos después de ti" (Dt 4, 40). La fórmula "escucha Israel" está repetida 80 veces solo en el Deuteronomio. La idea central del deuteronomista, "Escucha Israel" (Dt 6, 3, 4), es una exigencia que funda y renueva esencialmente la vida humana ante su Dios, implica a toda la persona, como ratifica Sánchez: "la declaración presente en estos dos versículos (Dt 6, 3, 4) viene a ser una fuerza creadora de identidad: Israel es Pueblo de Dios en la medida en que se mantenga unido a las implicaciones de esta confesión" (Sánchez, 2002, p. 190).

La fe de Israel se basa, ante todo, en la escucha y en la acogida en el corazón de la Palabra venida de Dios. Escucha que es acogida de la llamada de Dios y recepción responsable de sus mandamientos: "Desde el cielo te ha hecho oír su voz para instruirte, y en la tierra te ha mostrado su gran fuego, y de en medio del fuego has oído sus palabras" (Dt 4, 36). "Escucha, Israel, los preceptos y las normas que yo pronuncio hoy a tus oídos" (Dt 5, 1). En esta misma línea, "la fórmula escucha Israel se corresponde con la fórmula a menudo usada por el maestro de sabiduría para introducir su enseñanza 'Escucha, hijo mío' (Pr 1, 8; 4, 1, 10; 5, 7; 7 , 24; 23, 19). Al puesto de 'Israel' pasa el 'hijo'" (Prévost, 1991, p. 22).

Sobre la reflexión bíblica del corazón unido al tema de escuchar, Mourlon (1984) amplía diciendo que el corazón humano en la Biblia es el asiento de la vida psíquica, la inteligencia, la voluntad, la vida emotiva y la vida social, tanto que lo considera su centro: "el corazón es el centro y el todo de la persona, sede de la vida íntima del hombre: pensamiento, memoria, sentimientos, decisiones. Es ciertamente el centro decisivo de la personalidad" (p. 10). Con la posibilidad, por tanto, de abrirlo a Dios y su hablar (escucharlo) o endurecerlo (no escucharlo).

Igualmente, León-Dufour (1972) añade que el corazón en la Biblia es la fuente misma de personalidad consciente, inteligente y libre del ser humano. Por tal motivo, en toda la Biblia "corazón es el punto donde el hombre se encuentra con Dios" (p. 189), y por eso ante el llamado de Dios (su hablar) el hombre puede salir con dobleces (engaños): "Ved: su oído es incircunciso y no pueden entender. Ved: la palabra de Yahveh se les ha vuelto oprobio: no les agrada" $(\mathrm{Jr} 6,10)$; son incircuncisos de corazón $(9,25 ;$ Hch 7,51$)$. Tal es el pecado de los judíos: “¿Por qué no reconocéis mi lenguaje? Porque no podéis escuchar mi palabra" (Jn 8, 43).

Por su parte, Wolff (1997) descubre que la Biblia usa la palabra corazón la mayoría de las veces para relacionarlo con las actividades racionales y por eso dice que leb se traduciría mejor por espíritu que por corazón. Pareciera que la abundancia de conocimiento del hombre lo hace proceder de un oír que sabe aprender: "un corazón capaz atento para juzgar a tu pueblo" (1 Re 3, 9). Ello capacita para regir y para distinguir lo bueno y lo malo. El corazón se convierte en tesorería del saber y de los recuerdos: “¿Cómo puedes decir te amo, si tu corazón 
no está conmigo?" (Jc 16, 15). Abrir todo el corazón es comunicarle todo su saber (Jc 16, 17, 18). Escuchar con el corazón significa tanto disponerse a escuchar al otro en su intimidad como ofrecer al otro su intimidad. En el corazón también se tomarán las decisiones $(2 S 7,27)$, desde donde será posible llevar a término los planes de Dios para el hombre (Pr 4, 20-27). Así pues, el hablar de Dios va dirigido al corazón del hombre. Se refiere a algo que pretende alcanzar cambiar la voluntad de este (Os 2, 16 y ss.; Gn 34, 3). Se trata de provocar una decisión (Is 40, 2; 2 Cró 30, 22; 32, 6) para obrar con buena intención $(2 S 7,3)$ y así presentarse ante Dios e intentar sintonizar con él (1 S, 14, 6 y ss.; Is 10, 7; Sal 24, 4; 17, 3; 139, 23; Pr 21, 2).

En consecuencia, escuchar hace al ser humano discípulo de Dios, puesto que "la palabra divina es la fuente de toda sabiduría, el ideal no es, por tanto, adherirse a un maestro humano, sino ser discípulo de Dios mismo. La sabiduría divina personificada llama así a los hombres a escucharla y a seguir sus lecciones" (Prov 1, 20 y ss.; 8, 4 y ss.) (León-Dufour, 1972, p. 250). Por escuchar es que puede ser modelo de hombre el siervo de Yahveh: el que escucha como discípulo (Is 50, 4 y ss.). "Tener oídos es ser apto para comprender (Hch 2, 14) [...] Es este el sentido que tienen algunas expresiones típicamente semíticas" (Mourlon, 1984, p. 17). Los predicadores deuteronomistas hacen arrancar la vida de la escucha de la Palabra de Yahveh, interpretando de un modo la tradición del maná (Dt 8, 3).

Negarse a escuchar sería renunciar a la vida (Dt 32, 47; Am 8, 11; Is 55, 10 y ss.) y a la salvación escatológica (Is 35,5). Así, el ser humano se conoce a sí mismo realmente ante el llamamiento que recibe, que escucha y en la promesa que se le hace. Moisés no comprende nada hasta no escuchar y recibir la tarea y la promesa de Dios (Ex 3, 11 y ss.). En el texto de Jeremías: “Yo dije: ¡Ah, Señor Yahveh! Mira que no sé expresarme, que soy un muchacho" (Jr 1,6), se ve claramente que el ser humano bíblico se sabe existente ante el llamado de Dios. Por ende, "el hombre que cerrando su oído parte de sí mismo y en sí mismo permanece, no solo se hace inhumano entre los hombres; sino que se autodiviniza frente a Dios. Su piedad se hace impía: Prov 28, 9; Sal 40,7" (Wolff, 1997, p. 110).

\subsection{El ser humano escucha para responder a Dios}

Dice Latourelle et al. (1992): “Dios habla para ser escuchado (Hb 12, 25) y creído $(\mathrm{Hb} 4,2)$. Para suscitar la única respuesta del hombre: la fe" (p. 1235). Lo que se escucha desde el corazón y llega hasta la profundidad del ser es un oír que invita a dar una respuesta. Si ante la llamada la criatura humana se sabe la existente, con la respuesta se confirma como persona. El privilegio del ser humano, según 
el texto yahvista (Gn 2, 18-23), consiste en definitiva en que puede responder, gracias a la preeminente Palabra de Dios pronunciada como llamada. Con la palabra que es respuesta a Dios que le habla, el hombre se hace totalmente hombre (Wolff, 1997).

Un modo de responder a Dios es el hablar humano, es un acto que lo asemeja a Dios. Pero el hablar humano es respuesta razonada, querida y asumida desde abajo (condición frágil). Por tanto, es respuesta obediente a Dios, nunca es iniciativa ante Dios: "Abre, Señor, mis labios, y publicará mi boca tu alabanza" (Sal $51,17)$. Una vez que el ser humano escucha de verdad es capaz de responder a la palabra divina porque experimentó que alguien (Dios) movió su voluntad (Ex 35, $21 ; 36,2)$. Ante la palabra divina, el hombre se define como el que está disponible a seguirla, a asentirla, a llevarla a cabo: "Pero teniendo aquel espíritu de fe conforme a lo que está escrito: Creí, por eso hablé, también nosotros creemos y por eso hablamos" (2 Co 4, 13).

A esta respuesta humana también se le puede llamar entrega consciente de su voluntad a la de Dios (Dt 4, 29; 19, 12; 11, 18). El verdadero sentido de la obediencia es conocer con el corazón y seguir de buena voluntad los deseos de Dios (1 S 15, 6; 1 R 12, 27; Pr 23, 26). “La obediencia lejos de ser una sujeción que se soporta y una sumisión pasiva, es una libre adhesión al designio de Dios todavía encerrado en el misterio, pero propuesto por la palabra de la fe, que permite por tanto al hombre hacer de su vida un servicio de Dios y entrar en su gozo" (LeónDufour, 1972, p. 602). Este es el sentido del imperativo al shemá de Israel. Es el amor a Dios en el contexto de la Alianza. "Amor, temor, reverencia y obediencia se colocan en una misma línea, como actitudes básicas del israelita respecto de su Dios. Amar a Dios significa ser fiel y leal (Dt 7, 9; 11, 1; 30, 20), obedecer sus mandatos y servirle (11, 22, 19, 9)" (F. García, 1994, p. 22). En el lenguaje bíblico, los sustantivos corazón, alma y fuerzas son usados para referirse a la totalidad del ser humano, perfección que responde a un compromiso de amor. "El hombre en la totalidad de su existencia vive para amar a un solo Dios, el Señor" (Sánchez, 2002, p. 192).

Por tanto, responder a Dios supone hablar y obrar según Él lo espera. Como esto es imposible solo por el querer humano, la Biblia habla frecuentemente que el corazón que será capaz de responder adecuadamente a Dios es el de "carne", que el mismo Dios dará a quien se lo pida (Ez 11, 19; 36, 26; 1 S 25, 37; Ez 18, 31; 23, 31 y ss.). Hará falta, pues, un nuevo corazón y un nuevo espíritu para escuchar y responder adecuadamente a la Palabra. Gracias a esta escucha libre de la Palabra, el ser humano puede negarse a responder o responder contrariamente a los deseos de Dios. Ser sordo (Dt 18, 16, 19; Jr 6, 10; 9, 2, 5; Hch 7, 51) o duro 
de corazón $(E z 36,26)$ será para el pensamiento hebreo necedad o, en palabras actuales, inhumano. Este aspecto se verá más abajo.

\subsection{Cristo: plenitud humana de escucha y respuesta a Dios}

La escucha y respuesta obediente a Dios la plenifica Cristo. El misterio de la kenosis del Hijo muestra que Jesús se hizo no solo hombre sino siervo (cf. Mt 12, 18) y que "se despojó de sí mismo, tomando condición de esclavo. Asumiendo semejanza humana y apareciendo en su porte como hombre" (Flp 2, 7); además, "aun siendo Hijo, por los padecimientos aprendió la obediencia” (Hb 5, 8). Así se muestra el camino de escucha a la voluntad del Padre hasta aceptar el escándalo de la cruz: "Abbá, o sea, Padre, para ti todo es posible, aparta de mí esta copa. Pero no se haga lo que yo quiero, sino lo que quieres tú" (Mc 14, 36); "se rebajó a sí mismo, haciéndose obediente hasta la muerte y una muerte de cruz" (Flp 2,8). El Hijo de Dios mostró cómo ser plenamente humano escuchando al Padre y haciendo su voluntad. "De la misma manera que el Hijo del Hombre, no ha venido a ser servido, sino a servir y dar su vida como rescate por muchos" (Mt 20, 28).

¿Cómo y dónde escucha, Cristo, para guardar en su corazón lo que el Padre deseaba de él? En las Sagradas Escrituras (Mc 1, 11; Lc 4, 4, 8, 12, 18), en los hechos (Mt 11,4), en las personas y sus actitudes (Mt 15, 28), en sus padres terrenos (Lc 2, 49-51), en su condición de pobre (Lc 2, 6-15; Mt 2, 1-10), en la tradición y en los superiores (Mt 23, 3; Mc 7, 13; 1, 22), en el dolor (Lc 22, 43-44), en la oración (Lc $5,16 ; 6,12 ; 9,18,28-29 ; 11,1)$. Jesús hace suya, con sus palabras y con sus obras lo que reza el Salmo 40, 7-8: “No has querido sacrificio ni oblación, pero me has abierto el oído; no pedías holocaustos ni víctimas, dije entonces: Aquí he venido. Está escrito en el rollo del libro que debo hacer tu voluntad".

La condición de oyente del ser humano, por tanto, no solo lo coloca en el plano creatural ante Dios, sino también en su más alta dignidad: la de ser hijos de Dios, gracias a Cristo. Entonces, la finalidad última del diálogo Dios-ser humano no es otra que entrar en comunión con las tres Personas de la Trinidad.

\section{El diálogo Dios-ser humano: alianza de humanización}

Sin duda, uno de los conceptos fundamentales en la Biblia para hablar de la relación Dios-ser humano es el de Alianza: “He pensado establecer mi Alianza con vosotros y con vuestra futura descendencia" (Gn 9, 9). Entendida básicamente 
como una respuesta humana al llamado de Dios (Sal 25, 10, 14). Al manifestarse en la historia, el Dios bíblico desde el primer momento quiere definir su relación como un pacto entre amigos (en hebreo alianza = berit), pacto que debe realizarse entre iguales, por eso Dios crea al hombre a su imagen y semejanza. El pacto implica, además, el reconocimiento del carácter personal del otro y, por tanto, el reconocimiento de la libertad y de la voluntad soberana entre las partes, tipo de relación en la que cabe incumplir con el pacto.

Siendo la Alianza el acontecimiento configurador del pueblo israelita, ayudará a descubrir la profundidad del encuentro Dios-ser humano y de los seres humanos entre sí. En la Alianza, sigue la misma concepción bíblica de Yahveh como aquel que toma la iniciativa (Gn 9, 8 y ss.), es él quien promete (Gn 15, 18), por ello puede imponer unas normas (Dt 4,13) y, en consecuencia, al pueblo le toca el compromiso de fidelidad (Ex 19,8). Así como Dios inicia esta relación, será el ser humano quien la rompa, provocando el despliegue amoroso del Señor en una continua historia de salvación.

En la reflexión bíblica, se encuentran varias acepciones del término "alianza". La imagen yahvista de la Alianza en el Sinaí (Ex 24, 9-11) es unilateral, de protección al pueblo. En cambio, la imagen eloista (Ex 24, 3-8) coloca al pueblo frente a una decisión y se concluye con un documento. La ley aparece unida al ofrecimiento de gracia. En la teología deuteronomista, por su parte, alianza es sinónimo de mandamiento (Dt 9, 9, 11, 15; 10, 8; Nm 10, 33), mientras que en la comprensión sacerdotal es puro don salvífico de Yahveh (Gn 6, 18; 9, 1, 9, 11; 17, 1, 2, 6, 19, 21) unido a la promesa: "Yo seré tu Dios" (Von Rad, 1982, pp. 179-183). La reflexión profética le da a la Alianza una carga afectiva muy fuerte con las imágenes de rebaño-pastor, padre-hijo y esposo-esposa, para mostrar una relación de amor (Ez 16, 6-14) entre Dios y el pueblo de Israel (León-Dufour, 1972, p. 62). Dicho amor se debe traducir por parte del pueblo en obediencia y fidelidad una vez que ha elegido entre la vida y la muerte (Dt 30, 15), reflexión que procedía del pensamiento deuteronomista (Dt 4, 37; 6, 5; 7, 8; 10, 12, 15; 11, 1). Finalmente, en el pensamiento neotestamentario, Dios establece una nueva alianza con la humanidad en Jesucristo. Ante el fracaso de la Alianza sinaítica en la que el pueblo ha sido infiel en múltiples ocasiones, comenzó a surgir la idea de una nueva alianza mesiánica (Jr 31, 31-34; 33, 14-22), que será realidad con la venida de Jesús, Mesías enviado por Dios para renovar y plenificar su pacto con todos los seres humanos.

En la base de la teología de la alianza, está la voluntad salvífica de Yahveh, esto es, el profundo y eterno deseo de Dios de invitar a los hombres y a las mujeres, a los pueblos, a vivir en comunión con Él. La alianza es siempre oferta de Yahveh y el pueblo su destinatario. “Dios quiere asociarse a los hombres 
haciendo de ellos una comunidad cultual entregada a su servicio, regida por la ley, depositaria de sus promesas" (León-Dufor, 1972, p. 6). La alianza salvífica no está destinada al dominio despótico de Dios, sino al compromiso liberador de un Dios benevolente. En ella el pueblo descubre el carácter liberador de la obediencia y del servicio a Yahveh. Es alianza de comunión. Por ello, se puede definir el pacto del Dios con el ser humano, y viceversa, como una relación interpersonal, una alteridad interpelante y un evento re-creativo. La teología de la creación como la primera alianza, el Decálogo como dinámica del diálogo divino con su interlocutor (Pueblo) y la visión salvífica de alianza ante su ruptura por el ser humano serán argumentos que sustenten la triple dimensión del diálogo Dios-ser humano, ser humano-ser humano y ser humano-cosmos.

\subsection{Relación interpersonal}

\subsubsection{El ser humano creado a imagen de Dios es capaz de relacionarse con Él, con los demás y con el mundo}

Como bien lo recordaba Juan Pablo II, "en el contexto de aquel principio bíblico según el cual la verdad revelada sobre el hombre como 'imagen y semejanza de Dios' constituye la base inmutable de toda la antropología cristiana" (Mulieris dignitatem, n. 6), cada ser humano es imagen de Dios, lo manifiesta una nota esencial de su condición: la dignidad humana, porque refleja la gloria de Dios. Todo ser humano está por encima de los demás seres vivos (Sal 8): su vida es sagrada e inviolable y le pertenece solo a Dios. Es gracias a esta dignidad otorgada que le es posible relacionarse con su creador y responder a su razón de ser y existir: "la relación con Dios es la única plenitud del hombre" (Ladaria, 1997, p. 6). Con razón dice Ruiz de la Peña (1993):

Dios es el tú del hombre; el fondo último de lo humano es la apertura constitutiva, inexorable, a Dios. Pero, además (lo que es más sorprendente), el hombre es el tú de Dios. Cuando Dios mira a esa criatura suya, se encuentra reflejado en ella. Cuando Dios crea a Adán, no crea una naturaleza entre otras, ni una cosa entre otras, sino a su "tú". Y lo crea llamándolo por su nombre, poniéndolo ante sí como ser responsable (= dador de respuesta), sujeto e interlocutor de un diálogo interpersonal. (p. 66)

En el relato yavhista, crear al hombre no es solo darle vida (Gn 2, 7), es también establecer su entorno físico (Paraíso, Gn 2, 8), asignarle una tarea como ser 
activo (Gn 2, 15), recordarle su responsabilidad frente a Dios (Gn 2, 16-17), situarlo en un campo de relaciones con los demás seres (Gn 2,19-20) y, sobre todo, con su tú más próximo, la mujer (Gn 2, 21-24). “Esta múltiple relación: trabajo de la tierra, la condición mortal del hombre, su vida con la mujer y con los animales a los que dio nombre, está determinada por el vínculo fundamental con su creador [...] pero que con el hombre y su mujer entabla un diálogo como no existe con nadie más" (Wolff, 1997, p. 131). Solo en ese conjunto de relaciones el ser humano está completo. En el relato sacerdotal, el hombre es imagen de Dios porque domina. Como afirma Ruiz de la Peña (1988):

El verso Gn 1, 26 no ofrece una definición de hombre; resuelve el enigma del hombre con una descripción de su ser relacional; el ser humano es, primaria y constitutivamente, relación a Dios, imagen de Dios. Es una relación de dependencia absoluta, puesto que toda imagen recaba su propia consistencia y su razón de ser en el original que reproduce. (p. 45)

Ambos relatos expresan que el ser humano, creado a imagen de Dios, es relación al tú humano con relación de igualdad y, análogamente, en relación al tú divino con relación de dependencia. A la antropología bíblica le es ajena una concepción dualista o dicotómica; es holística, integracionista. Ve a la humanidad hecha de carne (basar), con aliento de vida (nefes), es receptora del espíritu de Yahveh (ruah). El ser humano es una unidad existencial, todo él (carne y espíritu) busca a Dios (quien a su vez le ha buscado primero) o todo lo rechaza, de acuerdo con la posibilidad de elección que le fue dada, porque el ser humano es ruah, es quien plasma la relación Dios-ser humano. Como bien dice Wolff (1997): "La manera especial de ser del hombre dentro de la creación hay que entenderla partiendo de su especial relación con Dios" (p. 215).

De la relación interpersonal Dios-ser humano se desprende la relación interpersonal ser humano-ser humano. El ser humano individual desde la creación no está aún completo. Para ejercer su interlocución trascendente, precisa de un interlocutor inmanente. Para ser el tú de Dios, necesita el tú humano, un ser semejante y diferente. El ser humano es carne (basar) junto a carne, una ayuda adecuada. Aquel ser que era solo un humano (Ha-Adam) irá haciéndose personal al descubrirse y realizarse en compañía, como varón y mujer (Gn 2, 21-25) y descubrirá también la cercanía y compañía de Dios. Se es humano en la comunidad interpersonal no en la soledad existencial, como bellamente lo expresa el texto sapiencial: "El Señor creó al hombre de la tierra [...] los revistió de una fuerza como la suya, a su propia imagen los creó [...] y a cada uno le dio preceptos acerca de su 
prójimo" (Si 17, 1, 3, 14). Por tanto, la persona humana se hace tal relacionándose personalmente con Dios y, como reflejo, con sus semejantes, es capaz de relacionarse fraternalmente con sus semejantes.

En el amor al tú humano, se cumple toda la Ley y los profetas. Este acto de amor es simultáneamente el más acrisolado acto de fe. Tal fe se confiesa mirando y tratando al otro como la imagen de Dios y mirarlo de otro modo es cosificarlo y por tanto la más evidente incredulidad. El ser del hombre, constitutivamente religado a Dios, hace que este pueda dialogar con otro hombre de tú a tú. Antes de que yo me dirija a él, él es ya un tú, alguien a quien el mismo Dios se ha dirigido (Ruiz de la Peña, 1988). Esta relación interhumana será plenificada en Cristo:

La antropología termina así, topándose con la cristología o se revela como una cristología incoada. Lo que el hombre es se nos descubre en la realización insuperable de lo humano del Dios hecho hombre. Si Cristo es el hombre por antonomasia, del que Adán era simple boceto (Rom 5,14), y si el ser personal de Cristo es puro relación a Dios Padre, el hombre será tanto más hombre cuanto más y mejor realice su relación a Dios en Cristo, es decir en tú humano sacramento de Cristo. (p. 184)

Dios, al crear al ser humano capacitado para dialogar interpersonalmente con Él y con sus semejantes, lo capacita también para relacionarse de modo personal con el cosmos. Está dentro de su dignidad de creado a semejanza de Dios, relacionarse con el mundo al modo como se relaciona el mismo creador con sus creaturas, porque "la criatura es lo que el creador ha querido llegar a ser. Dios no es solo el creador de un mundo distinto de él; Dios es, él mismo, criatura; la forma de existencia definitiva del Dios revelado en Cristo es la encarnación" (Ruiz de la Peña, 1993, p. 31).

Es una visión que comporta una actitud reverente y contemplativa en relación con la naturaleza. Un cosmos penetrado por la acción del Dios personal y dotado de una dimensión cristológica tan radical no puede ser reducido a mero instrumento para el provecho de nadie. El mensaje bíblico de la administración responsable de la naturaleza, "Y los bendijo Dios con estas palabras: Sed fecundos y multiplicaos, y henchid la tierra y sometedla" (Gn 1, 28), debe ir acompañado del respeto, la admiración y la acción de gracias ante un mundo tan rico en contenido simbólico-teológico. La antropología teológica que define al ser humano como un ser dialogante deja vislumbrar que el origen y la meta de esta relación interpersonal Dios-ser humano está en el misterio de la Trinidad:

El diálogo intradivino generador de las tres personas se prolonga a extramuros de la Trinidad inmanente para desplegarse en el marco histórico 
de la creación. Ésta culmina en la producción de un ser "imagen de Dios", capaz de escucha y respuesta. El hombre es querido y creado por Dios como estructura dialogante; también él es un ser responsorial, comunicativo, capaz de autodonación, cosas todas que el relato yahvista de la creación de Adán y Eva nos ha notificado ya. El ser humano es, en una palabra, un ser relacional; en él volvemos a toparnos con lo que hemos dicho que la relación significaba en la articulación trinitaria del ser divino: el hombre es persona. (Ruiz de la Peña, 1988, p. 157)

\subsubsection{Revelación: encuentro personal de Dios con el ser humano}

La concepción bíblica de la Revelación de Dios tiene un dinamismo dialógico en el cual Él invita a participar de su vida personal:

Este acontecimiento de la Revelación, sustentado por el Dios trinitario, y cuyos motivos son la bondad, la sabiduría y el amor de Dios, se describe en su índole propia como acontecimiento de encuentro personal que tiene como fin la comunión entre Dios y el hombre, y que, como acontecer personal, asocia los hechos y las palabras. Dios "habla a los hombres como amigos y trata con ellos" (n. 2), sale a su encuentro con amor, entabla diálogo con ellos (n. 21) y habla ininterrumpidamente con ellos (n. 8 y 25). En estrecha relación con esta manera de concebir la Revelación como un diálogo, se halla su fisonomía histórico-salvífica. (Schmitz, 1990, p. 91)

Sostiene Preuss (1999), al referirse a la autorrevelación de Dios: "esta palabra (de Yahveh) sucede, se hace para el encuentro personal con Yahveh" (p. 339). Dios "quiere ser para el hombre un yo que se dirige a un tú, en una relación interpersonal y vital, en resolución de comunicación, de diálogo, de participación" (Latourelle et al., 1992, p. 407), encuentro que provocará un autodescubrimiento del hombre, de su más esencial identidad (Pablo VI, 1968), así como permitirá descubrir la identidad del Dios revelante. La historia de la Revelación es la historia de un diálogo progresivo entre Dios y la humanidad, de una comunicación esencialmente personal. Como decía Pablo VI: "la historia de la salvación narra precisamente este largo y variado diálogo que nace de Dios y teje con el hombre una admirable y múltiple conversación" (Ecclesiam suam, n. 28).

La antropología bíblica refleja al hombre contento de serlo, consciente de sus posibilidades. Muestras de ello son los innumerables versos de los salmos 
de alabanza, en especial cuando canta el salmista sobre la creación del ser humano: "lo hiciste, coronándolo de Gloria y esplendor" $($ Sal 8, 6). Por eso se atreve a hablar con Dios confiadamente, basta leer el cuarto capítulo del libro de Job. "El hombre bíblico no es un ser anonadado ante la divinidad o inseguro. Sabe quién es" (Pastor, 1995, p. 41) y sabe que por ello puede acercarse a su Dios como alguien con quien puede relacionarse. "El Cantar de los cantares representa sin duda un momento privilegiado en el empleo de esta modalidad de Revelación. Con palabras de un amor profundamente humano, que celebra la belleza de los cuerpos y la felicidad de la búsqueda recíproca, se expresa igualmente el amor divino por su pueblo" (Ratzinger, 2004, n. 9). La Revelación es, pues, una experiencia del misterio en un encuentro, no solo del pasado:

Es mucho más que todo eso. Revelación quiere decir: arrancar el velo que cubre la realidad, y mostrar así, el rostro de Dios que allí se esconde y nos sonríe [...] Para que los hechos del pasado, narrados por la palabra de la Biblia, puedan arrancar el velo de los hechos de nuestra vida y revelarnos la presencia de Dios, es necesario que nosotros percibamos hoy el sentido que tales hechos del pasado tienen para nosotros. (Mesters, 1988, p. 132)

\subsubsection{Dios se revela como Padre}

La plenitud de la relación interpersonal que Dios establece con el ser humano es que se da a conocer como Padre. Si bien el Dios bíblico es el Dios soberano, también es Padre, características que explica Jeremías (1983):

Dos aspectos de la noción de padre, la autoridad absoluta y la misericordia, caracterizan al Dios-Padre que nos presenta el antiguo testamento. Este utiliza muy pocas veces (solo en quince ocasiones) el término "Padre" para designar a Dios. Con este nombre se honra a Dios como creador: “¿No es él tu Padre y tu creador?” (Dt 32, 6); “¿No tenemos todos un solo Padre? ¿No nos creó un mismo Dios?” (Mal 2, 10). (pp. 19-20)

Esta ternura paternal de Dios puede ser expresada también mediante la imagen de maternidad (Is 66, 13; Sal 131, 2), que indica más expresivamente la inmanencia de Dios, la intimidad entre Dios y su criatura (Catecismo de la Iglesia Católica, n. 239). La imagen de Dios y la imagen plena del ser humano la mostrará Cristo:

Si el hombre (Adam) era, en cuanto imagen de Dios, gestor y presidente de la creación, Cristo, la imagen arquetípica, lo es de forma acabada: 
"primogénito de toda la creación", la recapitula y confiere consistencia (Col 1, 15, 17, 18). A partir de aquí el destino del hombre no es ya ser imagen de Dios, sino imagen de Cristo. (Ruiz de la Peña, 1988, p. 79)

Es Jesús quien mostrará cómo está llamada a ser la relación Dios-ser humano-Dios. Esta será una relación filial de un hijo ante su Padre. Para él, Dios es alguien personal, un amor inteligente y libre, al que atribuye una voluntad concreta sobre sí mismo y sobre el mundo. Unas 170 veces Jesús se refiere al Padre en los Evangelios (109 en Juan, 42 en Mateo, 15 en Lucas y 4 en Marcos) (Jeremías, 1983), para decirnos que su primera y fundamental experiencia en el Espíritu es su relación personal y amorosa con su Padre, relación que supone una confianza gozosa y una obediencia radical. El Nazareno vive a Dios con la confianza ante su Abbá. En la tradición judía, no era común dirigirse al Padre como abbá, sino como abi o abinu (padre mío o padre nuestro). Abbá era demasiado confidencial (modo como los niños se relacionan con su papá), muy bien comentado por A. García (2003): "podemos perceber como Jesus viveu uma relação com Deus intensamente pessoal. A profunda intimidade afetuosa, entranhável, penetrada de ternura [...] unida á irrestrita confiança nesse Deus"' (p. 301).

La intimidad de Jesús confiada al Padre le proviene, pues, de su reciprocidad con él: "nadie conoce al Hijo sino el Padre, ni al Padre le conoce nadie sino el Hijo" (Mt 11, 27; Lc 10, 22). Jesús afirma que tiene la misma relación de mutuo conocimiento que tiene un hijo con su padre y lo que aprende de él, eso hace (Jn 5, 19). Nunca se calificó directamente del Hijo en sentido absoluto. Dios se le ha mostrado de manera total $y$, a través de él, se manifiesta definitivamente a la humanidad. El Padre es el símbolo religioso de un Dios comunicativo en el Jesús histórico, quien será portador definitivo y escatológico de esa comunicación divina.

De todo lo dicho en los últimos apartados, se deduce que la fe acontece como encuentro personal: "la Revelación, como la fe, se abre al misterio de una persona y no de una cosa: de un yo que se dirige a un tú; de un yo que, al descubrir el misterio de su vida, descubre al hombre; que todo el sentido de la existencia humana reside en el encuentro con ese yo y en la acogida del don que hace de sí mismo" (Latourelle et al., 1992, p. 1272). La antropología teológica sustenta, pues, con claridad la relación interpersonal del ser humano con Dios, con sus semejantes y con el cosmos, como dinámica propia de la alianza establecida. A continuación, se verá cómo esta misma relación interpersonal está enriquecida por un imperativo ético. 


\subsection{Relación interpelante}

En los términos de la Alianza Yahveh-Israel, la relación Dios-ser humano-ser humano tiene una dimensión ética ineludible. Este dato se encuentra en la ética del Decálogo en el Antiguo Testamento y del Reino que Jesús anuncia, así como en la experiencia de las primeras comunidades cristianas. Los fundamentos bíblicos de la relación interpelante Dios-ser humano y ser humano-ser humano, sin duda, están en la finalidad última de vida y salvación para todos. Como bien dice Von Rad (1982): "con los mandamientos, Yahveh ofreció la vida a su pueblo" (p. 251). Escucharlos y cumplirlos era saberse un pueblo sabio: "ciertamente esta gran nación es un pueblo sabio e inteligente" (Dt 4, 6b). Esta fue la finalidad que Jesús culminó: “Yo he venido para que tengan vida y la tengan en abundancia" (Jn 10, 10).

Para acercarse al Decálogo viene bien recordar que "el don del Decálogo fue concedido en el marco de la alianza establecida por Dios con su pueblo. Los mandamientos de Dios reciben su significado verdadero en y por esta alianza" (Catecismo de la Iglesia Católica, n. 2077). Así, se puede hablar de una relación interpelante: "Del Yo de Yahveh al tú del prójimo", como resume F. García (1994) el Decálogo, destacando que, en Ex 20, 2-6/Dt 5, 6-10, se dan los pronombres personales de primera y segunda persona del singular, referidos al yo de Yahveh y al tú de Israel, para señalar que Yahveh tiene la iniciativa y el pueblo escucha las pretensiones y exigencias de Yahveh (p. 15).

\subsubsection{El Decálogo en el Antiguo Testamento: salvaguarda de la ética de la fraternidad}

"Israel se concibe a sí mismo como una comunidad en alianza con Yahveh. Los que han sido objeto de la elección divina no son los individuos sino el pueblo: Dt 7, 6; 9, 26-29; 30, 15-20" (Ruiz de la Peña, 1988, p. 207). Con esto Israel se concebía indisolublemente unido entre sí por un vínculo: "Israel aprendió a interpretarse como una hermandad del Pueblo de Dios" (Wolff, 1997, p. 249). La comunidad es un organismo interlocutor de Dios, mediador de la salvación, depositario de las promesas. Dios, al proponer a los israelitas un pacto de amistad, pide de ellos el compromiso de vivir como hermanos y Dios por su parte se compromete a ayudarles a cumplirlo. Dios propone: "Yo seré el Dios de ustedes. Y ustedes serán mi pueblo" (Ex 6, 7; Jr 24, 7; 30, 22; 31, 1, 33; 32, 38; Ez 36, 28; Za 13, 9; Os 2, 23). Y ellos aceptan diciendo: "Haremos todo cuanto ha dicho el Señor" (Ex 19, 8). La Palabra de Dios se convierte en una interpelación ética para el pueblo a vivirse como tal. 
En los primeros mandamientos, Yahveh quiere dejar claro que la razón del compromiso que le pide al pueblo es honrar su Nombre y reconocerlo como su único Dios: "Yo soy Yahveh, que te ha sacado de la casa de la esclavitud" (Ex 20, 2; Dt 5, 6). Se identifica con autoridad por su intervención en la historia: "la acción salvífica divina fundamenta las exigencias de los mandamientos" (F. García, 1994, p. 17). Dios, centro de todo, se presenta con el título más grande que tiene ante los ojos del pueblo: su libertador. Dios no podía dialogar si no con un pueblo libre, para hacer una alianza voluntaria con él. Los esclavos no pueden formar un pueblo de hermanos.

En los siguientes mandamientos (Ex 20,12-17), se leen las leyes fundamentales de la vida en común. Los israelitas, liberados de toda esclavitud, podrán vivir como hermanos y harán posible una sociedad donde no reine la ley del interés propio de cada individuo, más bien como fundamento de la sociedad se pone a la familia $(20,12)$. Los otros fundamentos son el respeto a la vida ajena $(20,13)$, el respeto a la vida matrimonial $(20,14)$, el respeto a la pequeña propiedad ajena $(20,15)$ y el respeto a la fama del prójimo $(20,16)$. Respeto que ha de llegar hasta la profundidad de nuestros pensamientos $(20,17)$. Todo lo que conforma el "Código de la alianza" (Ex 20, 22-23, 19) se refiere a las leyes fundamentales de la vida comunitaria. Con ejemplos prácticos, enseña el respeto hacia toda persona humana $(21,2-11)$, el respeto a la vida $(21,12-32)$, el respeto a la pequeña propiedad de cada uno $(21,33$ al 22,15), el respeto a la mujer $(22,15-16)$. De lo que más habla es del derecho de los pobres (22, 20 al 23, 13). Manda insistentemente ayuda a los pobres: a todos se debe tratar como hermanos aun a los enemigos.

Todo este espíritu de servicio mutuo fue resumido en una frase: ama a tu prójimo como a ti mismo ( Lv 19, 34). La comparación es entre el prójimo y sí mismo, aquí se supera toda regla legal de la vida con los semejantes y se fundamenta una hermandad personal con cercanos y lejanos (Wolff, 1997). Israel aprendió a interpretarse como una hermandad del Pueblo de Dios. Esta interpretación tuvo consecuencias para la relación humana. El imperativo del Decálogo viene del otro, es causa de justicia que hace suya el Dios israelita. Esto no puede ser entendido sino en la gratuidad de la gracia y del amor misericordioso de Dios y de la respuesta generosa y fraterna del hombre, que será plenificada en Jesucristo a través del anuncio del Reino.

\subsubsection{El Reino en el Nuevo Testamento: un compromiso de humanización}

En el Nuevo Testamento, se vislumbra el nuevo Israel: la Iglesia, comunidad de la Nueva Alianza basada en el amor (Rm 12, 3-8; 1 Co 12, 12-30; Ef 4, 15-16). La 
ética del Decálogo fue consumada y plenificada por la ética del Reino. El Reino es para Cristo, principalmente, una respuesta de vida a la urgencia de los otros de su tiempo en coherencia con su misión de fiel Hijo del Padre. "Jesús no ha sido un racionalista crítico o un filósofo social, sino un profeta mesiánico, que, a la luz del anuncio del Reino, ha interpretado la voluntad de Dios con su vida hecha palabra, principio de transformación humana" (Pikaza, 2006, p. 214). Esta es la antropología bíblica del Reino: un compromiso de humanización.

Los Evangelios hablan de la centralidad del Reino en la vida de Jesús, básicamente como una realidad que engloba su persona y su misión. Los sinópticos, cuando quieren resaltar lo central de la vida y del mensaje de Jesús, lo resumen en el Reino de Dios: Basileía tôิ Theô̂. Muchas veces identifican al Reino de Dios con el Evangelio (Mc 1, 14-15; Mt 4, 23; 9, 35; 24, 14). Mateo usa las palabras Evangelio y Reino para expresar que lo que predicaba, vivía y obraba Jesús (Mt 26, 13) era Buena Noticia. En continuidad con el Antiguo Testamento: “El símbolo Reino evocaba en Israel la memoria de la actividad de Dios [...] Es el Dios que actúa en favor de su pueblo, y en última instancia a favor de la creación entera" (Fuellenbach, 1992, pp. 1116-1117). Entonces, se tienen que explicar las palabras junto a las obras de Jesús y descubrir en ellas la dimensión del significado del Reino de Dios. Jesús, consagrado por el Espíritu, proclamará el contenido de su misión: "me ha ungido, me ha enviado a anunciar a los pobres la Buena Nueva" (Lc 4, 18), como una realidad en su Persona y en la historia. "Esta Escritura, que acabáis de oír, se ha cumplido hoy" (Lc 4, 21). Se trata, pues, de la Buena Nueva del Reino, su itinerario de vida y misión, "la proclamación y la instauración del Reino de Dios son el objeto de su misión: 'porque a esto he sido enviado' (Lc 4, 43)" (Redemptoris missio, n. 13).

El mensaje de Jesús quiere acentuar la dimensión histórica del actuar divino y de manera especial acercarse al mundo social injusto y hacerlo su proyecto de vida. Esto es un proyecto interpelador y liberador en la misma dinámica del Dios del Antiguo Testamento: “Jesús asume el papel de anunciador de la próxima llegada liberadora de Dios rey que sigue siendo el único protagonista del acontecimiento esperado. Pero con esta particularidad: que él muestra una solidaridad afectiva con los oprimidos que proclama bienaventurados" (Barbaglio, 1994, pp. 76-77). De ahí que los milagros y las bienaventuranzas, como las parábolas, llevan consigo una interpelación a quienes, en nombre de su religión, apartan a las personas de su vida, de la sociedad. Jesús, en sus palabras y obras, respondía a algo que el pueblo deseaba y hasta necesitaba de manera apremiante y satisfacía aspiraciones y esperanzas hondas de los más pobres, ignorantes y marginados de aquella sociedad: 
El Reino de Dios llega a los seres humanos, ante todo, como liberación del sufrimiento, de la indignidad y de la muerte [...] el mandato de "anunciar que ya llega el Reino de Dios" va unido siempre al mandato paralelo de "curar enfermos" (Mt 10, 7; Lc 9, 2; 10, 8). Es decir esas curaciones son los "signos que prueban la realidad del Reino del Dios". (Castillo, 2001, pp. 65-66)

En última instancia, para Jesús, lo que hace posible captar la interpelación del otro es el amor, en el que resume y plenifica el Decálogo del Antiguo Testamento y se entiende el anuncio y la realización del Reino: “Os doy un mandamiento nuevo: que os améis los unos a los otros. Que como yo os he amado, así os améis también vosotros los unos a los otros" (Jn 13, 34). Y más adelante repite: “Este es el mandamiento mío: que os améis los unos a los otros como yo os he amado" (Jn 15, 12). Y vuelve a repetir por tercera vez: "Lo que os mando es que os améis los unos a los otros" (Jn 15, 17). Para Jesús, solo el amor al otro como otro es lo que verifica la fe en Dios y no al revés: “Quien no ama no ha conocido a Dios, porque Dios es Amor [...] pues quien no ama a su hermano a quien ve, no puede amar a Dios a quien no ve" (1 Jn 4, 7, 20). "La 'espiritualidad' expuesta por Jesús no era de carácter individualista, sino eminentemente social, orientada hacia la vida en comunidad" (Arens, 2010).

De esta enseñanza de compromiso con los otros hasta lograr la comunión fraterna, muy bien entendida y vivida, da testimonio la vida de los primeros cristianos que narra los Hechos de los Apóstoles $(2,4)$. De ellos se dijo, como menciona la carta a Diogneto: "cuál es ese amor que se tienen unos a otros" (Carta a Diogneto, n. 1), era porque lo vieron como una propuesta colectiva difícil para encarar una sociedad en conflicto y persecución, haciéndose "signo de contradicción". El testimonio de fidelidad personal se extendería a un testimonio de fidelidad comunitaria.

El diálogo Dios-ser humano se da como interpelación hacia la justicia y fraternidad, en una dinámica divino-humana de compromiso con la comunión Dios-ser-humano y entre los seres humanos. Esta dinámica, por el elemento de libertad y amor que conlleva, no puede dejar de contar, por un lado, con la fragilidad y el límite del ser humano, que pudiendo permanecer en alianza armoniosa con su Dios rompe muchas veces con el pacto establecido. Por otro lado, esta dinámica supone también el sorprendente e incansable reanudar la alianza de parte de Dios. 


\subsection{El ser humano rompe el diálogo con Dios y se deshumaniza}

En la dinámica de escucha, el ser humano como ser creado con inteligencia y voluntad puede hacerse sordo, rechazar la Palabra de Dios y negarse al diálogo con Dios. Por eso la antropología del Antiguo Testamento presenta dos caminos posibles para el ser humano, quien deberá elegir, muy bien destacada en la literatura deuteronomista: "pongo delante de ti la vida y la muerte, elige pues la vida" (Dt 30, 15). En Gn 2, 4b-24, se asegura que el futuro de la vida es don de Dios (vv. 15-16) y los seres humanos solo podrán conseguirlo en confianza dialogal con su creador. La plenitud del ser humano dependerá de entablar un "diálogo gratuito con Dios" y esta plenitud ha de expresarse en formas de vida social (Pikaza, 2006).

\subsubsection{Ruptura del diálogo con Dios}

La experiencia primera de infidelidad del pueblo israelita la vivió prevaricando contra Dios cuando lo quiere cambiar por un ídolo: “Anda, haznos un dios que vaya delante de nosotros, pues no sabemos qué ha sido de ese Moisés, que nos sacó del país de Egipto" (Ex 32, 1b). Israel prefiere un dios a su alcance a quien pueda manipular, prefiere no escuchar a Dios y por tanto rompe el diálogo en los términos propuestos por Dios. En lugar de mantener su lugar como criatura, quiere precederle, se niega a obedecerlo y a abandonarse en él confiadamente, se ha rebelado (Dt 9, 7). En el fondo, el pecado de idolatría significaría básicamente rechazar la presencia constante, protectora y liberadora de su Dios, para buscar otros que no le pidan responder responsablemente a mantener la amistad con Dios.

Este mismo sentido del rechazo del ser humano a Dios, más ampliamente descrita, se encuentra en la narración del pecado de Adán y Eva. El autor yahvista $(\mathrm{Gn} 3,11)$ no hace teoría del pecado, "su interés se concentra más bien en mostrar una cadena de sucesos reales, un camino que recorrieron los hombres y los condujo a una situación irreparable [...] No deberíamos llamar míticas estas narraciones que van desde el pecado original hasta la torre de Babel" (Von Rad, 1982, pp. 204-205). La Biblia ve en el conjunto de estas narraciones un elemento común: la ruptura de las relaciones originales con Dios: "la relación con Dios se encuentra negativamente afectada en las diversas nociones del mal, injusticia (opuesta a la justicia divina), ruptura con Dios" (Ladaria, 1997, p. 58).

De ahí que el árbol del conocimiento de lo bueno y lo malo es figura de un discernimiento de madurez del ser humano ante Dios, de buscarlo y hallarlo para 
su plenitud de vida como tal (Gn 2,17). Este, por su primera opción (tomar del árbol del bien/mal), conoció el fruto de una decisión que le llevó a una ruptura fundante de otras sucesivas, "intentó ensanchar su naturaleza hacia Dios, buscando un aumento de la vida divina más allá de sus límites creados"' (Von Rad, 1982, p. 206). Al elegir el camino que rompe el diálogo, el hombre prefiere el monólogo. Es suficiente su propio juicio, no importa el querer de Dios:

Esta es nuestra grandeza y pequeñez. El hombre puede trascenderse, recibiendo así por gracia el ser (amor) de lo divino. Pero también puede cerrarse en su interior, haciendo de su juicio un absoluto [...] El hombre es grande porque puede rechazar el amor. El pecado es la expresión invertida de esa grandeza: sin libertad no existe gracia; sin riesgo de pecado no habría salvación. (Pikaza, 1993, p. 94)

Pero ¿qué hay en el ser humano que lo condujo y conduce al monólogo? Sin duda, aquí hay que ponderar la diferencia de la palabra divina con la humana. Aquí la figura de la serpiente $(\mathrm{Gn} 3,1)$ muestra esta diferencia claramente. Siguiendo la reflexión de Pikaza, la serpiente no es una criatura, es un momento siempre amenazante y posible en el mismo diálogo del ser humano con Dios.

\subsubsection{Ruptura del diálogo con sus semejantes}

El ser humano pretende vivir separado de Dios, en contra de su plan, construir otra historia, pretensión que lo conducirá a su continua deshumanización:

Nuestra vida se podía haber desarrollado de otra forma y que las cosas del hombre no son lo que podían haber sido. En el fondo de la historia (del diálogo de Dios y de los hombres) se ha inscrito una ruptura. Por eso, el ser humano que hallamos al fin de ese relato (la caída) no es un ser "natural" (neutral) que vive conforme a sus valores y posibilidades, sino el hombre caído que ha quebrado el diálogo con Dios y corre el riesgo de romperse o destruirse como humano. (Pikaza, 1993, p. 79)

La Biblia ve el pecado como ruptura de esa relación fundante con Dios, que será también y a la vez ruptura de la relación interhumana:

Adán inocente había acogido a Eva para ser una carne con ella, pero Adán pecador se distanciará de ella responsabilizándola de su culpa (Gn 3, 12); Caín responde al ¿dónde está tu hermano? Con una declaración de afectada ignorancia que rechaza la idea de que el hombre solo puede ser responsable de sí mismo en tanto que se corresponsabiliza 
de su prójimo (Gn 4, 9); Lamec proclama jactanciosamente la ley del más fuerte (Gn 4, 23-24); la humanidad de Babel se fragmenta en una multitud que ya no puede comunicarse (Gn 11, 6-9). (Ruiz de la Peña, 1988, pp. 208-209)

Con la ruptura de la buena relación con Dios y con sus semejantes, el ser humano se estaba condenando a quedarse aislado, en la individualidad infecunda y deshumanizante. Optó por la violencia interhumana en lugar de una existencia compartida. En la ruptura, se conjugan varios mecanismos que conducen al monólogo: la desobediencia, la mentira, la envidia, la autojustificación, la autodivinización, la soledad ansiosa, la vergüenza que no soporta la mirada y el afán de independencia que aísla y separa del otro.

\subsubsection{Ruptura del diálogo para Jesús}

En el Nuevo Testamento, se ve que la raíz del pecado es no acoger el amor de Cristo. Jesús dirá con fuerza: "en lo referente al pecado, porque no creen en mí" (Jn 16, 9). "Todo el que permanece en él, no peca. Todo el que peca, no le ha visto ni conocido" (1 Jn 3, 6). Romper con Jesús es no querer mantener un diálogo amical y de discípulo. Eso es creer en Él: es adherirse a su persona, tenerlo como lo único importante (Lc 10, 42; Jn 8, 47); es llamarlo "Señor" solo si practicas lo que has oído de sus palabras, de lo contrario eres un insensato, un "agente de iniquidad" (Mt 7, 21, 23, 26; Lc 6, 46). Por eso criticará con fuerza el tipo de adhesión a Dios de los fariseos: “¡Ay de vosotros, escribas y fariseos hipócritas!” (Mt 23, 27), cuyo pecado fue no comprender quién es Dios realmente y qué tipo de relación les ha estado pidiendo a lo largo de su historia, concretada en Jesús.

El Nuevo Testamento muestra con mayor claridad que la ruptura del diálogo con Dios se manifiesta en la ruptura con el hermano. ¿A quién censura Jesús? Al que defendiendo la Ley quiere quitar la vida a sus semejantes (Jn 8, 4-11; 3940); al que creyendo cumplir los mandamientos de Dios no se porta como prójimo (Lc 10, 36-37; Mt 25, 41 y ss.); a quien defendiendo las normas del culto no da la mano al necesitado (Mc 2, 27; 3, 4; Lc 6, 5, 9; 13, 14 y ss.; Jn 5, 9, 10; 7, 23; 9, 14). A todos los que no entendieron que la medida del amor a Dios es el amor que Dios tiene por sus hijos: "que os améis los unos a los otros como yo os he amado" (Jn $15,12)$. Ya que se es mentiroso al decir que se ama a Dios y no se ama al hermano $(1 \mathrm{Jn} 4,8 ; 2,11 ; 3,15 ; 4,20)$. Todo esto para darse cuenta de que la comunión cristiana es el meollo y el eje transversal del Evangelio y por ende el no Reino es la no hermandad. 
Aunque el principio de comunión y de gracia sea interrumpido por el pecado (querer hacerse divino por sí mismo, cerrarse en sí y romper el diálogo con Dios y con su prójimo), la historia no se cierra aquí, sino que Dios vuelve a ofrecer su gracia como un llamado constante a la salvación, a la reconstrucción del diálogo. En Cristo muerto y resucitado, Palabra recreadora del Padre, se tiene la posibilidad de recobrar el diálogo interrumpido y restaurar la comunión con Dios y con los hermanos.

\subsubsection{Relación recreadora: humanidad resucitada}

Está en la espiritualidad de la antropología bíblica la visión de Dios que creó al ser humano para dialogar con Él y por su iniciativa amorosa le fue ofreciendo su amistad continua y progresivamente. Este, por su parte, fue acogiendo y rechazando las ofertas de Dios. En esta dinámica de la alianza rota y restablecida, es posible ubicar cómo se fue dando, junto a la relación interpersonal e interpelante, una relación recreadora.

La redención de Israel no es solo un perdón, sino un acto de creación. En toda obra salvífica, Dios es creador: "Así dice Yahveh tu creador" (Is 43,1 ; 44, 24-26). Para describir la salvación, el Deuteroisaías utiliza un vocabulario de creación. La creación inicial es una garantía, porque es ya principio de una salvación que Dios realizará más tarde en plenitud. La obra se consumará en el Espíritu [que] es soplo que resucita a los muertos (Ez 37, 1-14) [...] Israel será purificado por creación divina, en el poder y santidad del Espíritu. (Durrwell, 1979, p. 20)

La Biblia habla de Dios que viene a salvar (Is 35, 4). "La fe en Yahveh, es antes que nada fe en la elección, y por consiguiente fe en la salvación. Israel conoce a su Dios Yahveh y dio testimonio de él, principalmente como un Dios Salvador cuya Revelación consistió en una liberación" (Preuss, 1999, pp. 406-407). “A lo largo de su historia, Israel pudo descubrir que Dios solo tenía una razón para revelársele y escogerlo entre todos los pueblos como pueblo suyo: amor gratuito (Dt $4,37 ; 7,8 ; 10,15)$. Israel comprendió, gracias a sus profetas, que también por amor Dios no cesó de salvarlo (cf. Is 43, 1-7)" (Catecismo de la Iglesia Católica, n. 218). La experiencia de relación con Dios de los israelitas era de un encuentro salvífico: "Yahveh, mi roca y mi baluarte, mi liberador, mi Dios; la peña en que me amparo, mi escudo y fuerza de mi salvación, mi ciudadela y mi refugio" (Sal 18, 3). Los profetas anunciarán una "nueva alianza" en espera de una salvación más profunda que alcance dimensiones más hondas que la del Sinaí. Una alianza que 
“actúa sobre el corazón del hombre y obra una verdadera y auténtica renovación interior" (Pasquetto, 1997, p. 74), en el corazón y no en la Ley: "Y os daré un corazón nuevo, infundiré en vosotros un espíritu nuevo, quitaré de vuestra carne el corazón de piedra y os daré un corazón de carne" (Ez 36, 26).

Dios seguirá siendo Padre, a pesar de las debilidades, pequeñeces, miserias y rebeldías humanas. Seguirá llamando a vivir como hijos en la casa paterna y como hermanos entre sí (Is 63, 16; Sal 89, 21-22, 25, 28). Es desde este amor que promete su guía y su fuerza a través de su ley paterna, pues conducen por sus caminos (Sal 31, 3-4) que conllevan la misión de la fraternidad, centro del mensaje de la Alianza (Ex 19), que el hijo no deberá olvidar (Pr 3, 1; Gal 3, 24). La Revelación divina habla, pues, de un Dios Padre-Madre, que ama con ternura, consuela y refuerza la esperanza (Is 42, 1-2; 49, 14-16). Un Dios cuyas entrañas se conmueven (Jr 31, 20; Sal 25, 6-7).

La esperanza del Pueblo judío en el Dios que salva se cumplirá y plenificará en Cristo, prototipo del hombre nuevo y restaurador de la imagen desfigurada del ser humano por el pecado. Como bien describe largamente Pikaza (2006), Jesús es la realización de la nueva alianza entendida como salvación y gracia. Jesús, Palabra de Dios cumplida, ha ofrecido su experiencia y mensaje de gracia, abierta a la responsabilidad del amor que vincula a todos los seres humanos. Los cristianos entienden la vida y la muerte de Jesús como Revelación suprema de la gracia de Dios que ofrece su amor a los seres humanos precisamente allí donde estos quieren destruirla. Jesús había prometido el Reino de Dios y Dios ha mantenido su promesa al resucitarlo. El sepulcro vacío de Jesús es principio de una humanidad que ya no puede fundarse sobre la justicia de la ley, sino sobre la gracia.

Es desde el marco de la nueva y eterna alianza sellada por Jesús que es posible entender más claramente la tercera dimensión relacional de ella: una relación recreadora entre Dios-ser humano y ser humano-ser humano. Es, sobre todo, después de la experiencia pascual de Cristo que se entiende el sentido recreativo de la comunicación Dios-ser humano. Solo después de la Pascua, con la cristofanía, los discípulos (Lc 24, 31 y ss.) pueden tener una comprensión adecuada de la rica personalidad e identidad del maestro y por ello pueden relatar su vida en los Evangelios desde una mirada retrospectiva (Castillo y Estrada, 2004). Dios resucita a Jesús (Hch 2, 24; 3, 15; 4, 10; 10, 39-40) venciendo al pecado, a la muerte humanamente insuperables. Así la experiencia pascual se presenta como una nueva creación, Dios regala su propia vida en plenitud. "La pascua es, por tanto, 
el primer principio antropológico: para los cristianos la vida es don de amor que supera la muerte, es comunicación creadora" (Pikaza, 2006, p. 351).

Por ello, Pablo, testigo de haber sido recreado por Cristo resucitado, insistirá en decir que solo la experiencia pascual hace posible el hombre nuevo, solo Él da un significado cualitativamente distinto de la historia humana. Por eso el apóstol invita: "revestíos del Hombre Nuevo, creado según Dios, en la justicia y santidad de la verdad" (Ef 4, 24); "Así pues, si habéis resucitado con Cristo, buscad las cosas de arriba, donde está Cristo sentado a la diestra de Dios" (Col 3, 1). La experiencia pascual no es un hecho aislado ni un evento que saca de la historia, sino que coloca en ella, al ser humano, con nueva capacidad de lucha, de crítica y de esperanza. Vivir la esperanza cristiana es, pues, estar aguardando testimoniando a la vez ya en la historia el encuentro con el Cristo pascual e ir construyendo con Él los significados nuevos que hagan posible una comunidad cristiana resucitada siendo día a día: “Un solo Cuerpo y un solo Espíritu, como una es la esperanza a que habéis sido llamados" (Ef 4, 4).

\section{Conclusión}

La antropología cristiana ha ofrecido suficientes fundamentos teológicos sobre la dimensión dialógica del ser humano tanto con Dios como con los demás seres humanos. A partir de la experiencia de Dios que vivió el pueblo escogido, se ha constatado la raíz de la experiencia espiritual del diálogo. Dios entra en la historia hablando y siendo proximidad amistosa con el ser humano, proximidad que llega a su plenitud en el Verbo encarnado. El ser humano bíblico es definido así como el que escucha y responde a Dios y, en ello, halla su plenitud. Entonces acoge la palabra divina, la guarda en el corazón y la obedece como discípulo. Desde esta escucha responde como portavoz de Dios, se entrega como siervo y tiene la posibilidad de negarse o rechazar la Palabra. Así, será Cristo la plenitud del ser humano que escucha y responde a Dios como este lo espera de aquel.

Con todo lo cual, si el ser humano hace de su vida una continua escucha y respuesta obediente al plan salvífico de Dios, indefectiblemente se humanizarádivinizará a sí mismo y ayudará en la humanización-divinización de la sociedad y del mundo. Esta es la espiritualidad verdadera que se consigue experimentando el diálogo como experiencia de encuentro pleno con el Señor y con el ser humano. 


\section{Referencias}

Andrade, B. (1999). Dios en medio de nosotros: esbozo de una teología trinitaria kerigmática. Salamanca, España: Secretariado Trinitario.

Arens, E. (2010). Jesús, fundamento de la espiritualidad cristiana. Recuperado de https://es. scribd.com/document/138600351/Arens-Jesus-fundamento-de-la-espiritualidad

Balthasar, H. U. von (1985). La oración contemplativa. Madrid, España: Encuentro.

Barbaglio, G. (1994). Espiritualidad del Nuevo Testamento. Salamanca, España: Sígueme.

Castillo, J. M. (2001). El reino de Dios por la vida y la dignidad de los seres humanos. Bilbao, España: Desclée de Brouwer.

Castillo, J. M. y Estrada, J. A. (2004). El proyecto de Jesús. Salamanca, España: Sígueme.

Catecismo de la Iglesia Católica. (1992). Madrid, España: Asociación de Editores del Catecismo.

Dartigues, A. (1993). "La Revelación como autocomunicación divina en el misterio". En C. Izquierdo, J. J. Albiar, V. Balaguer, J. L. González-Alió, J. M. Pons y J. M. Zumaquero (Eds.), Dios en la palabra y en la historia: XIII Simposio Internacional de Teología (pp. 241-256). Pamplona, España: Universidad de Navarra.

Dei Verbum. Recuperado de http://www.vatican.va/archive/hist_councils/ii_vatican_ council/documents/vat-ii_const_19651118_dei-verbum_sp.html

Durrwell, F. X. (1979). La resurrección de Jesús: misterio de salvación. Barcelona, España: Herder.

Fuellenbach, J. (1992). Reino de Dios. En R. Latourelle y R. Fisichella (Dirs.). Diccionario de teología fundamental (pp. 1115-1126). Madrid, España: Paulinas.

García, A. (2003). A fé cristã em Deus Pai e a crítica freudiana da religião. Atualidade Teológica, 15, 296-322.

García, F. (1994). El decálogo. Navarra, España: Verbo Divino.

Jeremías, J. (1983). Abba: el mensaje central del Nuevo Testamento. Salamanca, España: Sígueme.

Ladaria, L. F. (1997). Teología del pecado original y de la gracia: antropología teológica especial. Madrid, España: Biblioteca de Autores Cristianos.

Latourelle, R., Fisichella, R. y Pié-Ninot, S. (Eds.) (1992). Diccionario de teología fundamental. Madrid, España: Paulinas.

Legido López, M. (1987). Misericordia entrañable: historia de la salvación anunciada a los pobres. Salamanca, España: Sígueme.

León-Dufour, X. (1972). Vocabulario de teología bíblica. Barcelona, España: Herder. 
Mesters, C. (1988). Por detrás de las palabras. Cuenca, Ecuador: Imprenta del Arzobispado.

Mulieris dignitatem. Recuperado de https://w2.vatican.va/content/john-paul-ii/es/ apost_letters/1988/documents/hf_jp-ii_apl_19880815_mulieris-dignitatem.html

Mourlon, P. (1984). El hombre en el lenguaje bíblico. Navarra, España: Verbo Divino.

Pablo VI. (1964). Ecclesiam suam. Recuperado de http://w2.vatican.va/content/paul-vi/ es/encyclicals/documents/hf_p-vi_enc_06081964_ecclesiam.html

Pablo VI. (1968). Jesucristo, Iglesia y fe: comentarios de teología pastoral a la luz del Concilio Vaticano II. Salamanca, España: Sígueme.

Pablo VI. (1998). Encíclicas de Pablo VI. Madrid, España: Edibesa.

Pasquetto, V. (1997). Llamados a una vida nueva: temas de espiritualidad del Antiguo Testamento. Ciudad de México, México: Carmel Maranatha.

Pikaza, X. (1993). Antropología bíblica: del árbol del juicio al sepulcro de pascua. Salamanca, España: Sígueme.

Pikaza, X. (2006). Antropología bíblica: tiempos de gracia. Salamanca, España: Sígueme.

Preuss, H. D. (1999). Teología del Antiguo Testamento. Volumen VI: Yahveh elige y obliga. Bilbao, España: Descleé de Brouwer.

Prévost, J.-P. (1991). Diccionario de los salmos. Navarra, España: Verbo Divino.

Rad, G. von. (1982). Teología del Antiguo Testamento. Vol. 1. Salamanca, España: Sígueme.

Rahner, K. (1967). Oyente de la palabra: fundamentos para una filosofía de la religión. Barcelona, España: Herder.

Ratzinger, J. (2004). Carta a los obispos de la Iglesia católica sobre la colaboración del hombre y la mujer en la Iglesia y el mundo. Recuperado de: http://www.vatican.va/roman_ curia/congregations/cfaith/documents/rc_con_cfaith_doc_20040731_collaboration_sp.html

Redemptoris missio. Recuperado de http://w2.vatican.va/content/john-paul-ii/es/encyclicals/documents/hf_jp-ii_enc_07121990_redemptoris-missio.html

Ruiz de la Peña, J. L. (1988). La imagen de Dios: antropología teológica fundamental. Santander, España: Sal Terrae.

Ruiz de la Peña, J. L. (1993). Creación, gracia y salvación. Santander, España: Sal Terrae.

Sánchez, E. (2002). Comentario bíblico iberoamericano: Deuteronomio. Buenos Aires, Argentina: Kairós.

Schmitz, J. (1990). La Revelación. Barcelona, España: Herder.

Sicre, J. (1992). Profetismo en Israel. El profeta. Los profetas. El mensaje. Navarra, España: Verbo Divino. 
Vergauwen, G. (1993). Revelación y narración. Navarra, España: Univerisdad de Navarra.

Wolff h, W. (1997). Antropología del Antiguo Testamento. Salamanca, España: Sígueme. 